CORRECTION

\title{
Correction to: Redefining intestinal immunity with single-cell transcriptomics
}

Kylie Renee James, Rasa Elmentaite, Sarah Amalia Teichmann and Georgina Louise Hold

(C) The Author(s) 2022

Mucosal Immunology (2022) 15:526; https://doi.org/10.1038/s41385-022-00483-1

Correction to: Mucosal Immunol https://doi.org/10.1038/s41385021-00470-y, published online 30 Nov 2021.

The original version of this article unfortunately contained a mistake. Due to a typesetting error Box 1 was omitted. We apologize for the error. Box 1 can be found below. The original article has been corrected.

\begin{abstract}
(c) (i)
Open Access This article is licensed under a Creative Commons Attribution 4.0 International License, which permits use, sharing, adaptation, distribution and reproduction in any medium or format, as long as you give appropriate credit to the original author(s) and the source, provide a link to the Creative Commons license, and indicate if changes were made. The images or other third party material in this article are included in the article's Creative Commons license, unless indicated otherwise in a credit line to the material. If material is not included in the article's Creative Commons license and your intended use is not permitted by statutory regulation or exceeds the permitted use, you will need to obtain permission directly from the copyright holder. To view a copy of this license, visit http://creativecommons. org/licenses/by/4.0/.
\end{abstract}

(c) The Author(s) 2022

Box 1: Areas of open investigation

- Resolving the positioning of intestinal cells using in situ transcriptomics.

- Integration of scRNAseq with other modalities e.g., metatranscriptomics, metabolomics, proteomics

- Systematic analysis of therapeutic mechanisms in in vitro and models systems.

- Cross tissue analysis i.e., common cell types and movement of cells between organ systems. 